\title{
AUDIT COMMITTEE CAPABILITIES AND INTERNET FINANCIAL REPORTING OF LISTED FINANCIAL FIRMS IN NIGERIA
}

\author{
Johnson Kolawole Olowookere \\ Department of Accounting, Osun State University, Osun State, Nigeria \\ Email: johnson.olowookere@uniosun.edu.ng \\ Tirimisiyu Kunle Lasisi \\ Department of Accounting, Federal University of Lafia, Lafia, Nasarawa State, Nigeria. \\ Email: tiriadio@yahoo.com
}

\begin{abstract}
The aim of this research is to look into the impact of audit committee capabilities and internet financial reporting on Nigerian listed financial firms. For this study, a correlation research design was used. All fifty-two (52) financial firms listed on the Nigerian Stock Exchange as of April 2020 make up the study's population. A total of 44 financial firms listed on the Nigeria Stock Exchange were sampled using a judgemental sampling process. Secondary data for measuring internet financial reporting transparency was extracted from the investor relations sections of each sample firm's corporate website, while secondary data for measuring audit committee capabilities came from the non-financial information section of the sampled firms' annual reports for a five-year period spanning the 2014 to 2018 financial years. The researchers used a pool of ordinary linear regressions to analyse the results. The validity of statistical inferences was tested using a diagnostic test. The study's results reveal that audit committee operation and competency have a significant positive relationship with internet financial reporting. Meanwhile, there is no connection between audit committee independence and audit committee size and internet financial reporting. As a result, the study suggests that regulators allow businesses to disclose financial details through their websites. A series of lectures or workshops should be held to inform the board and management about how the implementation of internet financial reporting will draw in more shareholders, increase transparency, and save money, according to the analysis. This study is restricted to only listed financial firms in Nigeria. Therefore, the findings of this study cannot be generalised. Because this study is limited to listed financial firms in Nigeria, future research can be expanded to other business sectors.
\end{abstract}

Keywords: Board Audit Committee, Internet Financial Reporting, Audit Committee Size, Voluntary Disclosure, Audit Committee Competency.

\section{INTRODUCTION}

The internet has evolved into the most efficient means of disseminating and sharing a wide variety of financial and non-financial information about companies with users (Green \& Spaul, 1997). The stress of disseminating paper-based financial statements to consumers has been minimized thanks to online 
financial reporting (Gowthorpe \& Flynn, 1997). The use of the internet to disclose corporate financial information has improved overall transparency, reduced information asymmetry, and raised public awareness of company results (Kelton \& Yang, 2008; Puspitaningrum \& Atmini, 2012). The audit committee, as a key component of corporate governance, is responsible for overseeing financial statements, accounting practices and standards, disclosure procedures, performance, independence, and controlling the internal control process in organizations. According to Akhtaruddin and Haron (2010), an audit committee is a control system that reduces information symmetry. According to Mallin (2007), the audit committee oversees and reviews financial reporting procedures and serves as a liaison between internal and external auditors, as well as managers and executives, to ensure a consistent and error-free flow of information and reporting transparency. The audit committee keeps an eye on businesses to ensure that investors' interests are protected. The details presented by the company assist investors in making decisions on whether or not to stay with a particular company, and they are provided by the Internet Financial Reporting System (IFR).

According to previous audit committee literature, an audit committee's efficacy is determined by its characteristics (Akhtaruddin \& Haron, 2010; Dhaliwal et al., 2010). The effectiveness of committees has had a major impact on internet financial reporting, according to Bin-Ghanem and Ariff (2016). In contrast, Kelton and Yang (2008) discovered that the audit committee's number of meetings and financial experience had a major impact on internet financial reporting. Abdillah (2016a) also discovered that the financial experience of the audit committee had a substantial positive impact on internet financial reporting, while the number of audit committee meetings had no significant effect. The audit committee's ability to carry out its duties effectively is thus dependent on a reliable combination of experience, knowledge, scale, and capabilities. (Madi et al., 2014). Online financial reporting (IFR) activities are usually voluntary and uncontrolled, despite the advantages of the internet as a medium for sharing corporate information (Dutta \& Bose, 2007). As a result, internet financial reporting (IFR) disclosure practices are left to the discretion of administrators, creating questions about the accuracy of the information reported to outsiders (Kelton \& Yang, 2008).

According to Section 359 (3) of the Company and Allied Matters Act, CAMA (2004) as amended, which mandates the formation of Audit Committees for public companies in Nigeria, "the auditor shall, in the case of a public company, also make a report to an Audit Committee which shall be established by the Public Company. "This provision was strengthened further by Section 359 (4), which requires that the committee be formed of an equal number of directors and shareholders' representatives, with a maximum of six members. The clause requiring the establishment of Audit Committees in Public Businesses in Nigeria was strengthened further in 2003 by the Securities and Exchange Commission's Code of Best Practices for Corporate Governance in Nigeria, which was applicable to all public 
companies in Nigeria. According to (Nat, 2013), the 2003 SEC Code required corporations to form Audit Committees and further specified that the Audit Committee should include directors' representatives. The 2003 SEC Code has been superseded by the Securities and Exchange Commission's 2011 Code of Corporate Governance in Nigeria, which was effective on 1st April 2011. Perhaps taking a cue from the 2003 SEC Code, the Central Bank of Nigeria's Code of Corporate Governance for Banks in Nigeria Post-Consolidation, which is mandatory for all banks operating in Nigeria, also includes a provision requiring the establishment of audit committees in all banks operating in Nigeria. Additionally, the National Insurance Commission's (NAICOM) Code of Corporate Governance for Insurance Businesses in Nigeria provides for the establishment of Audit Committees for Insurance and Reinsurance companies operating in Nigeria. The Audit Committee, on the other hand, received only a passing mention in two provisions of the National Pension Commission's (PENCOM) Code of Corporate Governance for Licensed Pension Operators; the first provision recognises the Audit Committee as one of the Committees that the Board of Directors of a relevant company may establish to facilitate its work, and the second provision stipulates that the. (National Geographic, 2013).

The relationship between audit committee characteristics and internet financial reporting has been the subject of many research studies. Nonetheless, the findings are inconsistent (Kelton \& Yang, 2008; Puspitaningrum, \& Atmini, 2012). In Nigeria, several studies on internet financial reporting have been conducted. Mustafa, Salaudeen, and Lasisi (2018) investigated the impact of corporate governance mechanisms on internet financial reporting of Nigerian listed companies. Foreign ownership, institutional ownership, business organisation size, and profitability were also investigated as factors affecting internet financial reporting by Mustafa and Lasisi (2018). Agboola and Salawu (2012) looked into the impact of firm size, profitability, and gearing on voluntary web disclosure by Nigerian commercial banks; Monday and Nancy (2016) looked into the impact of firm size, profitability, and gearing on voluntary web disclosure by Nigerian commercial banks; and Yusuf (2013) looked into the relationship between internet financial reporting and profitability, leverage, company size, and forecasting. While many studies have looked into the level of internet financial reporting and its determinants, researchers are aware of only a few that have looked into the impact of audit committee capabilities on internet financial reporting in Nigeria. As a result, by analyzing the impact of audit committee capabilities (audit committee operation, audit committee competency, audit committee independence, and audit committee size) on internet financial reporting (IFR) of listed financial firms in Nigeria, this study will make a significant contribution to filling a gap in the current literature. 


\section{LITERATURE REVIEW}

The effect of corporate governance on internet financial reporting was investigated by Kelton and Yang (2008). Shareholder interests, ownership structure, board composition, and audit committee characteristics are all factors in the report. The magnitude of each sample firm's IFR was measured using a disclosure index that took into account presentation style, information quality, and corporate governance disclosures. According to the study's findings, firms with weak shareholder rights, a lower percentage of block holder ownership, a higher percentage of independent directors, a more diligent audit committee, and a higher percentage of audit committee members who are considered financial experts are more likely to engage in IFR.

Yap, Saleh, and Abessi (2011) looked into the link between corporate governance processes, ownership structures, internet visibility, and financial reporting on the internet. The institutional theory was used to generate hypotheses about Malaysian-specific factors. The study examined the contents of listed companies' websites using the FASB's richer and more comprehensive disclosure/attributes index (2000). The regression model results show that independent non-executive directors, directors with accounting and business qualifications, board size, and shareholder numbers are all positively significantly related to Internet financial reporting. The results also show that having a financial and accounting qualified audit committee is favourably correlated with Internet visibility. These results indicate that, in response to technological complexity, qualified directors and accounting professionals are establishing good reporting practices to construct homogeneous organizational practices.

The relationship between corporate governance mechanisms and the level of internet financial reporting by Indonesian companies was investigated by Puspitaningrum and Atmini (2012). All 420 Indonesian companies listed on the Indonesian Stock Exchange (IDX) in 2010 are included in the study population. Purposive sampling was used to select 95 companies for the analysis. The data was analysed using multiple regression. The findings show that only the frequency of audit committee meetings influences voluntary disclosure of internet financial reporting among corporate governance mechanisms.

The impact of audit committee characteristics on internet financial reporting (IFR) of listed companies in Bahrain was investigated by AlMatrooshi, Al-Sartawi, and Sanad (2016). The research is being conducted in the Kingdom of Bahrain throughout 2014.For Bahraini listed firms, the multi-regression test was used to assess the relationship between audit committee characteristics and IFR. The study's findings revealed that there is a negative association between audit committee characteristics and internet financial reporting, implying that audit committee characteristics have little bearing on financial information disclosure over the internet. In the meantime, the board's and Big4's frequency of meetings culminated in a good partnership with internet financial reporting. The effectiveness of the board of directors and audit committee on the basis of Internet Financial Reporting (IFR) disclosure activities was 
investigated by Bin-Ghanem and Ariff (2016). The research looked at 152 publicly traded financial firms in Gulf Cooperation Council countries (GCC). To determine the degree of IFR disclosure, the researchers used content analysis based on a weighted index of 35 IFR products. The data was analysed using multiple regression analysis in this report. The study's findings indicate that the performance of the board of directors and audit committee has a substantial impact on the extent of IFR disclosure.

The impact of corporate governance and ownership structure on internet financial reporting in manufacturing companies in Indonesia was investigated by Hezadeen, Djamhuri, and Widya (2016). The study's population was made up of publicly traded firms on the Indonesia Stock Exchange in 2015. Filter parameters were used to screen 137 manufacturing firms. The findings showed that board of management competency, board of director meetings, and audit committee competence all have a positive impact on financial reporting on the internet. However, the findings revealed that the size of the board of directors has a negative impact on internet financial reporting. Furthermore, there is no evidence that audit committee independence, audit committee size, audit committee operation, ownership concentration on the top 5 shareholders, or multiple shareholders influence internet financial reporting.

The effectiveness of the board of commissioners and audit committees on internet financial reporting was investigated by Jao, Mediaty, Hamzah, Winar, Laba (2019). A purposive sampling technique was used to select samples from the financial partners listed on the Indonesia Stock Exchange. In 2017, data was gathered from the company's annual report and website. For data interpretation, the thesis used multiple linear regressions. The study's results revealed that the effectiveness of the board of commissioners had no significant impact on internet financial reporting, while the effectiveness of the audit committee had a positive and significant impact on internet financial reporting.

Salawu (2013) investigated the scope and types of voluntary financial information disclosure on the internet in Nigeria. Secondary data was used in the analysis. A total of 155 financial and non-financial companies listed on the Nigerian Stock Exchange (NSE) were chosen for the study. Data on financial reporting on the internet was gathered from the websites of the companies in the study. Data was analysed using content and descriptive analyses. According to the findings, 139 firms, or 90 percent of the listed companies, have websites, while 16 (10 percent) do not. Websites are used by $98 \%$ of the financial industry, which includes banking, insurance, mortgages, and other financial institutions. Just 77 (55 percent) of the 139 firms that had a website reported financial information on their pages, while the remaining 62 (45 percent) did not. 
Adebimpe and Ikenna (2013) looked at financial reporting on the internet and firms characteristics. According to the findings, 80.8 percent of Nigeria's publicly traded companies have websites, while 19.2 percent do not have websites or do not have websites that are available. The financial sector has the most companies with official websites (55), while the manufacturing sector has the most companies without official websites (14). The results of the regression analysis show that the internet financial reporting (IFR) index has a significant relationship with business size (log of total assets) and the industrial sector. However, the IFR index did not find profitability, auditor form, or business age to be important explanatory variables.

Agboola and Salawu (2012) looked into the major factors that influence financial reporting on the internet in Nigeria. Secondary data was gathered from the 77 sample firms' annual reports and accounts, as well as the Nigerian Stock Exchange's annual publications. Two major factors affecting IFR in Nigeria were discovered in the study. The scale of the company had a constructive and important relationship with the IFR practice. As a result, larger companies use IFR rather than their smaller counterparts. The findings also revealed that the form of auditor was important and beneficial to all of the businesses.

In Nigeria, Yusuf (2013) looked at internet corporate news. An internet financial reporting index was used to research the companies listed on the Nigerian Stock Exchange (IFRI). The relationship between (IFRI) and profitability, leverage, scale, international listing, and industry type was studied using multiple regression analysis. The empirical result shows that the size of the business is the only aspect that has a substantial impact on the level of internet financial reporting.

In a study of internet financial reporting by commercial banks in Nigeria, Sanni, Akinpelu, Fatona, and Olatunde (2009) discovered that all of the banks sampled had websites and that the majority $(77 \%)$ of them maintained some kind of financial information on the internet. They found, however, that only a handful of the banks had information that was comprehensive enough to be useful to customers, and that the majority of the information on the banks' websites was outdated.

Factors influencing financial internet reporting were investigated by Mustafa and Lasisi (2018). A sample of 125 companies listed on the Nigeria Stock Exchange were studied for foreign ownership, institutional ownership, company size, and profitability. The study used secondary data from the Investor Relations pages of each sample firm's corporate website and annual reports of the sample firms, which were analysed using panel data from 2010 to 2014. The data was analysed using pool multiple regression. The findings show that internet financial reporting has a significant positive relationship with international ownership, institutional ownership, and firm size, but a significant negative relationship with the profitability of the company. 
Mustafa, Salaudeen, and Lasisi (2018) investigated the impact of corporate governance mechanisms on listed companies' internet financial reporting in Nigeria. To study a total of 125 companies listed on the Nigeria Stock Exchange, the study used an ex-post facto research design and a stratified sampling process. The study used panel secondary data from the Investor Relations sections of each sample firm's corporate website, as well as annual reports from the sampled companies, for a five-year period from 2012 to 2016. Pool ordinary least regression was used to analyze the data. The findings show that board independence, board size, board competence, and board diligence all have a significant positive relationship with internet financial reporting. Gender diversity on the board, on the other hand, has no impact on internet financial reporting.

\section{CONCEPTUAL FRAMEWORK AND HYPOTHESES DEVELOPMENT}

This section addresses conceptual concerns such as audit committee capabilities, internet financial reporting, and the advancement of hypotheses.

\subsection{Audit Committee Activity and Internet Financial Reporting}

Abbott, et al. (2004) discovered that the number of meetings held each year represents the committee members' ongoing commitment to discussing any auditing-related problems in order to aid progress. These findings suggest that audit committees that meet regularly are more proactive in carrying out their responsibilities. The audit committee can meet three to four times a year to efficiently carry out the duties and responsibilities of the company's financial reporting system. Bronson et al. (2006) discovered that the number of audit committee meetings is linked to management reports' voluntary disclosure of internal controls. Firms with a more proactive audit committee are more likely to participate in internet financial reporting, according to Kelton and Yang (2008). (IFR). Furthermore, Puspitaningrum and Atmini (2012) found that only the frequency of audit committee meetings affects voluntary disclosure of internet financial reporting among the corporate governance standards of ownership, independent commissioner, and audit committee characteristics. The research has resulted in the creation of a testable hypothesis based on the analysis of prior studies.

Ho1: There is no connection between audit committee activity and financial reporting on the internet.

\subsection{Audit Committee Competency and Internet Financial Reporting}

The audit committee members must have two key competencies: financial reporting expertise and the ability to interpret reporting (financial reporting knowledge), and an understanding of the essence and function of financial report auditing (financial report auditing knowledge) (audit report knowledge). According to Velte and Stiglbauer (2011), the audit committee representatives' financial experience 
offers a foundation for reducing knowledge asymmetries between the management board and the audit committee, as well as the respective organization costs. The audit committee's financial experience, according to empirical evidence, improves the consistency of financial reporting. The audit committee's financial and governance experience is linked to perceived financial efficiency and Internet financial reporting (Kelton \& Yang, 2008). Andrea and Yang (2008) discovered evidence that audit committee competency has a positive impact on IFR. As a result, based on previous research, this study established a testable hypothesis.

Ho2: Audit committee competency and internet financial reporting have a negative relationship.

\subsection{Audit Committee Independence and Internet Financial Reporting}

The audit committee must be independent of the company's management in order to protect shareholders' interests and perform its oversight function. The board should form an audit committee with a minimum of three members, the majority of whom must be independent, according to the MCCG (Revised, 2007). Members of the audit committee can only be non-executive directors. To minimize agency costs, Patelli and Prencipe (2007) argue for the coexistence of independent directors and voluntary disclosure. Independent directors can restrict the agent's opportunistic actions, reducing the agent's benefit from withholding such details. According to previous research, there are two explanations for increased oversight of audit committee director independence. First and foremost, independent directors can be hampered in their ability to challenge management because they have no financial or psychological links to the business (Baysinger \& Butler, 1985; Carcello \& Neal, 2003). Second, independent audit committee members have distinct reasons for better monitoring the growth and maintenance of reputational resources. Furthermore, Abbott and Parker (2000) suggest that the audit committee service will help independent directors improve their status as financial watchdogs. An independent audit committee, as demonstrated by Bliss, Muniandy, and Majid (2007), serves as a significant check on CEO supremacy. Independent audit committees, according to empirical evidence, will improve financial reporting efficiency and enhance a company's internal controls (Abbott \& Parker, 2000; Abbott \& Peter, 2004; Bliss et al., 2007). As a result of the above discussions, the study established a testable hypothesis as follows:

Ho3: There is no connection between audit committee independence and financial reporting on the internet. 


\subsection{Audit Committee Size and Internet Financial Reporting}

The audit committee must also have at least three members, according to the Code of Corporate Governance (2000). According to Raghunandan \& Rama (2007), the composition of the audit committee affects the number of meetings. It is suggested that increasing the frequency of meetings would result in more efficient supervision. Vafeas (1999) argued, however, that a larger audit committee may result in inefficient governance due to the frequent meetings that result in increased expenses. Firms with a higher percentage of audit committee members who are considered financial experts are more likely to participate in IFR, according to Kelton and Yang (2008). According to Beasley (1996), the size of the committee is positively related to their ability to monitor disclosure decisions, while Bushee et al. (2014) reported that such conduct is considered inadequate governance due to a lack of accountability and honesty in the company's management and control. Following a study of previous research, a testable hypothesis has been established.

Ho4: There is no significant relationship between the size of an audit committee and financial reporting on the internet.

\section{METHODOLOGY}

Since the study tests relationships between audit committee capabilities and internet financial reporting of listed financial firms in Nigeria, it uses a correlation analysis design. As at April. 2020, the total number of only financial firms in Nigeria Stock Exchange is fifty-two (52), therefore, this made up of the study's population. These financial institutions were chosen because of their unique significance to Nigeria's economy. The sample for this study is calculated using the judgemental sampling process, which is based on the following four (4) criteria: (i) the companies must have websites that publish financial and non-financial information; (ii) the websites must not be under construction; (iii) the companies must have all available data during the study period; (iv) the company must have been listed a year prior to 2014. It is only forty-four (44) financial firms that have complete data for the periods of study, therefore, they were selected as sample size for this study. Secondary panel data were collected from selected forty-five (44) listed financial firms on the Nigeria Stock Exchange for the report. The data for the dependent variable of internet financial reporting was obtained from the websites of the selected companies, while the data for audit committee capabilities was obtained from the non-financial statements portion of the annual reports and accounts of sample listed financial firms in Nigeria for the five (5) years financial periods from January, 2014 to December, 2018. In the study, the STATA software was used to analyse the data on the relationship between audit committee capabilities and internet financial reporting running pooled ordinary least square (POLS) regression analysis. To ensure 
the reliability of the data, the researchers employed diagnostic tests for normality, multicollinearity, and heteroskedasticity. As Gujarati and Porter (2009) point out, the main goal is to protect against deception.

\subsection{Variables}

Internet financial reporting is the dependent variable, while audit committee activity, audit committee competency, audit committee independence, and audit committee size are the independent variables.

\subsubsection{Dependent Variable}

The internet financial reporting is the study's dependent variable. Al Arussi, Selamat, and Hanefah (2011) used the Internet Disclosure Index to calculate internet financial reporting (IFR) in their study. The Internet Disclosure Index (INTDI) is calculated based on a 37-item checklist (see Appendix). A dichotomous scoring system was used, with an object receiving a 1 if it was revealed and a 0 if it was not. The IFR disclosure index is calculated using the following model:

INTDI = $\quad$ the total number of items revealed

The total number of items that are supposed to be revealed (i.e. 37 )

\subsubsection{Independent Variables}

The research evaluates audit committee activity, audit committee competency, audit committee independence, and audit committee size as four explanatory variables based on a review of previous studies.

Audit Committee Activity: is measured as number of audit committee meetings held during the year (AlMatrooshi, Al-Sartawi \& Sanad, 2016).

Audit Committee Competency: is measured as the percentage of audit committee members who are financial experts (Kelton \& Yang, 2008).

Audit Committee Independence: is measured as the ratio of audit committee members who are independent over the period of the year (AlMatrooshi, Al-Sartawi \& Sanad, 2016).

Audit Committee Size: is measured as the number of audit committee members during the fiscal year (AlMatrooshi, Al-Sartawi \& Sanad, 2016). 


\subsection{Model Specification}

Based on theories and models adopted by AlMatrooshi, Al-Sartawi, and Sanad (2016); Kelton and Yang (2008), this study then modified their model specification as stated below:

$$
\begin{gathered}
\text { INTDIit }=\beta 0+\beta 1 \text { AUDCMAit }+\beta 2 \text { AUDCMCit }+\beta 3 \text { AUDCMIit }+\beta 4 \text { AUDCMSit } \\
+\varepsilon i
\end{gathered}
$$

Where:

INTDIit $=$ Internet disclosure index for the company in i year $t$

$\beta 0=$ Coefficient of the constant variable

AUDCMAit $=$ Audit committee activity for the company in $i$ year $t$

AUDCMCit $=$ Audit committee competency for the company in $i$ year $t$

AUDCMlit $=$ Audit committee independence for a company in i year $t$

AUDCMSit = Audit committee size for a company in i year $t$

$\beta 1, \beta 2, \beta 3, \beta 4,=$ Regression coefficients of independent variables

$\varepsilon i=$ error term.

\section{FINDINGS}

\subsection{Descriptive Statistics}

\begin{tabular}{|c|c|c|c|c|}
\hline Variables & Minimum & Maximum & Mean & Standard Deviation \\
\hline INTDI & 24.21 & 60.01 & 40.85073 & 10.23589 \\
\hline AUDCMA & 3 & 8 & 4.363636 & 1.048829 \\
\hline AUDCMC & 0.1666667 & 0.6666667 & 0.3257576 & 0.1437848 \\
\hline AUDCMI & 0.1666667 & 0.8 & 0.5070888 & 0.1293533 \\
\hline AUDCMS & 3 & 7 & 5.340909 & 1.149611 \\
\hline
\end{tabular}

TABLE 1: DESCRIPTIVE STATISTICS

Table 1 reveals the descriptive statistics of the variables of the study. It showed that internet financial reporting (INTDI) has a minimum value of 24.21 with a maximum value of 60.01 while the mean value and standard deviation value are 40.85073 and 10.23589 respectively. However, the minimum and maximum values of audit committee activity (AUDCMA) are 3 and 8 respectively while the mean value is 4.363636 with a standard deviation of 1.048829 . Moreover, the results from table 1 disclosed that mean of the audit committee competency (AUDCMC) of the sample firms is 0.3257576 with a standard deviation of 0.1437848 while the minimum and maximum proportional values are 0.1666667 and 0.6666667 respectively. Furthermore, the descriptive findings revealed that the mean value of audit 
committee independence (AUDCMI) is 0.5070888 with a standard deviation of 0.1293533 , and the minimum and maximum proportion values are 0.1666667 and 0.8 , respectively. Furthermore, the sample firms' minimum and maximum proportion of audit committee size (AUDCMS) are 3 and 7 , respectively, with a standard deviation of 1.149611 and a mean value of 5.340909 .

\subsection{Correlations Matrix}

The results from table 2 of the correlation matrix showed that all four independent variables audit committee activity (AUDCMA), the audit committee competency (AUDCMC), audit committee independence (AUDCMI), and audit committee size (AUDCMS) are positively correlated with internet financial reporting (INTDI). However, the results from table 2 that the highest correlation between independent variables is 0.35 , and that occurred between audit committee competency and audit committee size. Judge, Griffiths, Hill, Luthepohl, and Lee (1985) suggest that simple correlation between independent variables should not be considered harmful until they exceed 0.8 or 0.9 .

TABLE 2: CORRELATION MATRIX OF DEPENDENT AND INDEPENDENT VARIABLES

\begin{tabular}{l|lllll} 
& INTDI & AUDCMA & AUDCMC & AUDCMI & AUDCMS \\
\hline INTDI & 1 & & & & \\
AUDCMA & 0.2007 & 1 & & & \\
AUDCMC & 0.1428 & -0.2693 & 1 & & \\
AUDCMI & 0.0057 & 0.1047 & 0.1967 & 1 & 1 \\
AUDCMS & 0.0636 & 0.00671 & -0.3526 & -0.2199 & 1 \\
\hline
\end{tabular}

Source: Output generated using STATA 13.

\subsection{Diagnostic Test}

Based on the assumptions of regressions concerning panel data, which require the model to be fit and unbiased for valid interpretations and conclusions, this study, therefore, carried out multicollinearity and homoskedasticity tests.

\subsubsection{Multicollinearity Test}

The study carried out a multicollinearity test to check if the high correlations exist between independent variables which will mislead the result of the study. The study used variance inflation factor (VIF) and the tolerance value as an advance measure to check for the existence of multicollinearity. The general rule is that if the variables have a VIF greater than 10 and tolerance values less than 0.10 , there is a strong indication of multicollinearity (Gujarati \& Porter, 2009). Table 3 shows that there is no problem with multicollinearity because all tolerance values are greater than 0.10 and all VIF are less than 10 . 
Olowookere, J.K., \& Lasisi T.K.

AUDIT COMMITTEE CAPABILITIES AND INTERNET FINANCIAL REPORTING OF LISTED FINANCIAL FIRMS IN

NIGERIA

TABLE 3: RESULTS OF MULTICOLLINEARITY TEST

\begin{tabular}{l|ll} 
Variables & VIF & Tolerance \\
\hline AUDCMC & 1.26 & 0.791491 \\
AUDCMS & 1.17 & 0.852054 \\
AUDCMA & 1.11 & 0.901602 \\
AUDCMI & 1.10 & 0.910195 \\
\hline Mean VIF & 1.16 & \\
\multicolumn{2}{c}{ Source: Output generated using STATA 13. }
\end{tabular}

\subsubsection{Heteroskedasticity Test}

The study carried out a homoskedasticity test as one of the assumptions of multiple regression which state that the variance of the errors must be constant. If the errors do not have a constant variance, they are said to be heteroskedastic (Gujarati \& Porter 2009). However, the Breusch-PaganlCook-Weisberg test was employed to test the presence of heteroskedasticity. Based on the result from table 4 which showed the $p$-value is greater than $5 \%$. Therefore, there is no evidence for the presence of heteroskedasticity.

TABLE 4: BREUSCH-PAGAN / COOK-WEISBERGTEST FOR HETEROSKEDASTICITY

\begin{tabular}{|l|c|c|}
\hline Test & Chi-square & Prob>chi2 \\
\hline Breusch-Pagan / Cook-Weisberg & 3.29 & 0.0696 \\
\hline
\end{tabular}

Source: Output generated using STATA 13.

\subsection{Regression Results}

Table 5 presents the results obtained from regression analysis.

TABLE 5: REGRESSION RESULTS

\begin{tabular}{lccc}
\hline Model Summary & & & \\
\hline No. of Observation & & 220 & \\
F-statistic & & 6.03 & \\
Prob. > F & & 0.0001 & \\
R-square & 0.1008 & \\
Adj. R-squared & 0.0841 & Sig. \\
\hline Variables & Coefficient & t-statistic & 0.000 \\
\hline AUDCMA & 2.632469 & 3.96 & 0.000 \\
AUDCMC & 19.27367 & 3.72 & 0.488 \\
AUDCMI & -0.69 & 0.064 \\
AUDCMS & -3.723874 & 1.86 & 0.002 \\
(Constant) & 1.162718 & 3.16 & \\
\hline
\end{tabular}

Source: Output generated using STATA 13. 


\section{DISCUSSIONS}

In line with results from table 5 regression, the audit committee activity (AUDCMA) has a coefficient value of 2.63 , and a p-value of 0.000 . The positive coefficient value indicates that there is a significant positive relationship between audit committee activity and internet financial reporting of Nigerian listed financial firms. This means that for every one unit increase in audit committee activity among Nigeria's publicly traded financial companies, their internet financial reporting increases by 2.63 percent. AlMatrooshi, Al-Sartawi, and Za Sanad all came to the same conclusion as this report (2016). Meanwhile, the results of this study contradict those of Parlakkaya, Kahraman and Cetin (2015), who found no connection between the frequency of board audit meetings and internet financial reporting. According to the regression results in table 5 , audit committee competency has a coefficient value of 19.27 , and a p-value of 0.000 , indicating that it is less than a $5 \%$ degree of significance. Therefore, there is a positive significant relationship between audit committee competency and internet financial reporting of listed financial firms in Nigeria. This result is consistent with our a priori expectation. This implies that for every unit increase in audit committee competency, listed financial firms in Nigeria's internet financial reporting would increase by 19.27 percent. The study's results are consistent with those of Kelton and Yang (2008), but they contradict those of Yap, Saleh, and Abessi (2011).

The audit committee independence has a coefficient value of -3.72 , and $p$-value of 0.488 , which is higher than the $5 \%$ level of significance, according to the regression results in table 5 . This shows that audit committee independence has no significant relationship with internet financial reporting of listed financial firms in Nigeria. Based on our predictions, this result is not what we predicted. This means that the audit committee's proportion of independent directors has no bearing on the extent of internet financial reporting. This study's findings are consistent with those of AlMatrooshi, Al-Sartawi, and Za Sanad (2016) and Yap, Saleh, and Abessi (2011), who found no connection between audit committee independence and internet financial reporting. Meanwhile, the results of this research contradict those of Parlakkaya and Cetin (2015), who discovered a significant connection between several independent directors and internet financial reporting in their study.

The outcomes from table 5 shows that the scale of the audit committee has a coefficient of 1.16 while the significant value is 0.064 , which is greater than the $5 \%$ level of significance. This, on the other hand, revealed that there is no connection between the size of the audit committee and the financial reporting of listed financial firms in Nigeria on the internet. Based on this finding, the number of directors who join audit committees has no bearing on the extent to which listed financial firms in Nigeria disclose financial reports on the internet. This outcome is not what we expected based on our assumptions. This study's findings are consistent with those of Yap, Saleh, and Abessi (2011), but they contradict those of Kelton 
and Yang (2008); AlMatrooshi, Al-Sartawi, and Sanad (2016), who found an important positive relationship between board audit committee size and internet financial reporting.

\section{CONCLUSIONS}

It is concluded that there is a positive significant relationship between audit committee activity (meeting) and internet financial reporting of listed financial firms in Nigeria. This suggests that audit committee activity (meeting) has an effect on the quality of internet financial reporting. The frequent board audit meeting will encourage the disclosure of financial records on the internet. Furthermore, the study finds that audit committee competence has a major positive impact on financial reporting on the internet. This suggests that financial companies with a larger number of directors with financial experience on the board audit committee are more likely to publish their financial data on the internet. Furthermore, the study finds that audit committee independence has little bearing on internet financial reporting. Finally, the study finds that the scale of the audit committee has no bearing on the amount of online financial reporting. As a result, the study suggests that regulators allow businesses to disclose financial details through their websites. A series of lectures or workshops should be held to inform the board and management about how the implementation of internet financial reporting will draw in more shareholders, increase transparency, and save money, according to the analysis.

\section{REFERENCES}

Abbott, L., Parker, S. and Peters, G. (2004). Audit committee characteristics and restatements. A study of the efficacy of certain blue-ribbon committee recommendations. Auditing. A Journal of Practice and Theory, 23, 69-87.

Abbott, L.J. \& Parker, S. (2000). Audit committee characteristics and auditor choice. Auditing. A Journal of Practice and Theory, 19(2), 47-66.

Abdillah, M. R. (2016a). pengaruh efektivitas komite audit terhadap pengungkapan internet financial reporting (IFR) (studi empiris pada perusahaan manufaktur yang terdaftar di Bursa Efek Indonesia Tahun 2013). Dinamika Ekonomi-Jurnal Ekonomi dan Bisnis, 7(2).

Adebimpe, O. U. \& Ikenna, E. A. (2013). Internet financial reporting and company characteristics: A case of quoted companies in Nigeria. Research Journal of Finance and Accounting, 4(12), 7280.

Agboola, A. A., \& Salawu, M. K. (2012). The determinants of internet financial reporting: Empirical evidence from Nigeria. Research Journal of Finance and Accounting. 3(11), 95 - 105.

Akhtaruddin, M., \& Haron, H. (2010). Board ownership, audit committees' effectiveness, and corporate voluntary disclosures. Asian Review of Accounting, 18(3), 245-259.

Al Arussi, A. S., Selamat, M. H., \& Hanefah, M. M. (2011). The determinants of internet financial disclosure: The perspective of Malaysian listed companies. International Journal of Management Studies, 18(1), 1-29. 
AlMatrooshi, S.A.S., Al-Sartawi, A.M.A., \& Sanad, Z. (2016). Do audit committee characteristics of Bahraini listed companies affect the level of internet financial reporting? Corporate Ownership and Control Journal, 13(2), 130-146.

Baysinger, B.D. \& Butler, H.N. (1985). Corporate governance and the board of directors: performance effects of changes in board composition. Journal of Law, Economics and Organisation, 1(Fall), 101-124.

Beasley, M. (1996). An empirical analysis of the relation between the board of director composition and financial statement fraud. The Accounting Review, 71, 443-465.

Bliss, M.A., Muniandy, B. \& Majid, A. (2007). CEO duality, audit committee effectiveness and audit risks: a study of the Malaysian market. Managerial Accounting Journal, 22(3), 716-728.

Bronson, S.N., Carcello, J.V., \& Raghunandan, K. (2006). Firm characteristics and voluntary management reports on internal control. Auditing 25(2), 25-39.

Bushee, B, Carter, M, \& Gerakos, J. (2014). Institutional investor preferences for corporate governance mechanisms. Journal of Management Accounting Research, 26(2), 123-149.

Carcello, J.V., \& Neal, T.L. (2003). Audit committee characteristics and auditor dismissals following "new" going concern audit reports. The Accounting Review 75(1), 95-117.

Dhaliwal, D., Naiker, V., \& Navissi, F. (2010). The association between accruals quality and the characteristics of accounting experts and mix of expertise on audit committees. Contemporary Accounting Research, 27(3), 787-827.

Dutta, P. and Bose, S. (2007). Web-based corporate reporting in Bangladesh: an exploratory study. The Cost and Management, 35(6), 29-45.

Gowthorpe, C. \& Flynn, G. (2001). Smaller listed companies' financial reporting on the internet 2000/2001, Institute of Chartered Accountants in England and Wales, London, UK.

Green, G. \& Spaul, B. (1997). "Digital Accountability", Accountancy, International Edition, May, 49-50.

Gujarati, D. \& Porter, D. (2009). Basic Econometrics, 5th edition, New York: McGraw-Hill.

Hezadeen, A.H., Djamhuri, A., \& Widya, Y. (2016). Corporate governance and internet financial reporting in Indonesia: an empirical study on Indonesian manufacturing companies. The International Journal of Accounting and Business Society, 24(2), 36-47.

Jao, R., Mediaty, Hamzah, D., Winar, K., \& Laba, A. (2019). The effect of the board of commissioners and audit committees' effectiveness on internet financial reporting. International Journal of Academic Research in Accounting, Finance and Management Sciences, 9(2), 37-48.

Kelton, A. S. \& Yang, Y. (2008). The impact of corporate governance on the internet financial reporting. Journal of Accounting and Public Policy, 27, 62-87.

Madi, H, Ishak, Z, \& Manaf, N. (2014). The impact of audit committee characteristics on corporate voluntary disclosure. Procedia - Social and Behavioural Sciences, 164, 486-492.

Mallin, C. (2007). Corporate governance. New York, Oxford University Press.

Monday, I. I. \& Nancy, A. (2016). Determinant of voluntary disclosure quality in emerging economies: Evidence from firms listed in Nigeria Stock Exchange. International Journal of Research in Engineering \& Technology, 4(6), 37-45.

Mustafa, M.O.A \& Lasisi, T.K. (2018). Determinants of internet financial reporting: Evidence from selected companies listed on Nigeria stock exchange. International Journal of Innovative Research and Advanced Studies, 5(1), 232-241. 
Mustafa, M.O.A., Salaudeen, Y.M., \& Lasisi, T.K. (2018). Corporate governance mechanism and internet financial reporting of listed companies in Nigeria. Research Journal of Finance and Accounting, 9(14), 90-101.

Nat, O. (2013). An appraisal of audit committees of public companies in Nigeria. Available online at: http://ssrn.com/abstract=1641603 (Accessed on 20/06/2021).

Parlakkaya, R, Kahraman, U. \& Cetin, H. (2015). The effects of corporate governance on the level of internet financial reporting: evidence from Turkish companies. International Journal of Social, Behavioral, Educational, Economic, Business and Industrial Engineering, 9(3), 920-924.

Patelli, L. \& Prencipe, A. (2007). The relationship between voluntary disclosure and independent directors in the presence of a dominant shareholder. European Accounting Review, 16(1), 5-33.

Puspitaningrum, D., \& Atmini, S. (2012). Corporate governance mechanism and the level of internet financial reporting: Evidence from Indonesian companies. Procedia Economics and Finance, 2, 157-166.

Raghunandan, K., \& Rama, D. (2007). Determinants of audit committee diligence. Accounting Horizons, 21(3), 265-279.

Salawu, M. K. (2013). The extent and forms of voluntary disclosure of financial information on the internet in Nigeria: An exploratory study. International Journal of Financial Research, 4(1), 110119.

Sanni, M. R., Akinpelu, Y. A., Fatona, L. A. \& Olatunde, J. O. (2009). 'Internet financial reporting by commercial banks in Nigeria', Economic and Policy Review, 15(4).

Vafeas, N. (1999). Board meeting frequency and firm performance. Journal of Financial Economics, $53(1), 113-42$.

Velte, P. \& Stiglbauer, M. (2011). Impact of audit committees with independent financial experts on accounting quality. An empirical analysis of the German capital market. Problems and Perspectives in Management, 9(4), 17-33.

Yap, K., Saleh, Z, \& Abbesi, M. (2011). Internet financial reporting and corporate governance in Malaysia. Australian Journal of Basic and Applied Sciences, 5(10), 1273-1289.

Yusuf (2013). Internet corporate financial reporting: A study of quoted Nigerian companies. African Journal of Accounting, Auditing, and Finance, 2(3) 233-259.

\section{APPENDIX}

1A. Financial Information Disclosure Checklist

\begin{tabular}{|l|l|}
\hline S/N & Content \\
\hline 1 & Quarterly report of the current year \\
\hline 2 & Quarterly report of past years \\
\hline 3 & Half-year report of the current year (interim statements) \\
\hline 4 & Half-year report of past years (interim statements) \\
\hline 5 & Annual report of the current year (full text) \\
\hline 6 & Annual report of past years (full test) \\
\hline 7 & Annual report of the current year (excerpt) \\
\hline 8 & Annual report of past years (excerpt) \\
\hline 9 & Auditor report of the current year \\
\hline 10 & Auditor's report of past years \\
\hline
\end{tabular}


Olowookere, J.K., \& Lasisi T.K.

AUDIT COMMITTEE CAPABILITIES AND INTERNET FINANCIAL REPORTING OF LISTED FINANCIAL FIRMS IN

NIGERIA

\begin{tabular}{|l|l|}
\hline 11 & Statement of Financial Position (Balance Sheet) of the current year \\
\hline 12 & Statement of Financial Position (Balance Sheet) of past years \\
\hline 13 & Income statement of the current year (Profit and loss account) \\
\hline 14 & Income statement of past years \\
\hline 15 & Cash flow statement of the current year \\
\hline 16 & Cash flow statement of past years \\
\hline 17 & Notes to financial statements for the current year \\
\hline 18 & Notes to financial statements of past years \\
\hline 19 & Segmental reporting by a line of business in current year annual Report \\
\hline 20 & Summary of the key ratio over at least three years \\
\hline 21 & Five Years Financial Summary \\
\hline 22 & Accounting policies \\
\hline 23 & The information providing a dividend reinvestment plan \\
\hline 24 & Value Added Statement \\
\hline 25 & Chairman's Report \\
\hline 26 & Annual Report in PDF format \\
\hline 27 & Annual Report in HTML format \\
\hline 28 & Members of the Board of Directors \\
\hline 29 & Statement of Changes in Shareholders' Equity \\
\hline 30 & Corporate Social Responsibility Report \\
\hline 31 & Historical share prices \\
\hline 32 & Code of conduct and ethics for directors, officers, and employee \\
\hline 33 & Shareholder information \\
\hline 34 & Directors shareholding information \\
\hline 35 & Annual general meetings information \\
\hline 36 & Link to Nigeria Stock Exchange websites \\
\hline 37 & Projected information \\
\hline
\end{tabular}

Source: Adapted from Salawu (2012)

\section{1b. Data Output Generated from Stata 13.}

\section{Descriptive Test}

tabstat intdi audcma audcmc audcmi audcms, statistics( mean max min sd)

\begin{tabular}{r|rrrrr} 
stats | & intdi & audcma & audcmc & audcmi & audcms \\
mean | & 40.85073 & 4.363636 & .3257576 & .5070888 & 5.340909 \\
max | & 60.01 & 8 & .6666667 & .8 & 7 \\
min | & 24.21 & 3 & .1666667 & .1666667 & 3 \\
sd | 10.23589 & 1.048829 & .1437848 & .1293533 & 1.149611
\end{tabular}


Olowookere, J.K., \& Lasisi T.K.

AUDIT COMMITTEE CAPABILITIES AND INTERNET FINANCIAL REPORTING OF LISTED FINANCIAL FIRMS IN NIGERIA

\section{Correlation Test}

correlate intdi audcma audcmc audcmi audcms

(obs=220)

intdi audcma audcmc audcmi audcms

\begin{tabular}{r|rrrrr} 
intdi & 1.0000 & & & & \\
audcma & 0.2007 & 1.0000 & & & \\
audcmc & 0.1428 & -0.2693 & 1.0000 & & \\
audcmi & 0.0057 & 0.1047 & 0.1967 & 1.0000 & \\
audcms & 0.0636 & 0.0671 & -0.3526 & -0.2199 & 1.0000
\end{tabular}

Multicollinearity Test

estat vif

\begin{tabular}{rrr} 
Variable | & VIF & 1/VIF \\
audcmc | & 1.26 & 0.791491 \\
audcms | & 1.17 & 0.852054 \\
audcma | & 1.11 & 0.901602 \\
\hline Mean VIF | & 1.10 & 0.910195 \\
\end{tabular}

Heteroskedasticity Test

. estat hettest

Breusch-Pagan / Cook-Weisberg test for heteroskedasticity Ho: Constant variance

Variables: fitted values of intdi

$\begin{array}{llr}\text { chi2(1) } & =3.29 \\ \text { Prob }>\text { chi2 } & =0.0696\end{array}$




\section{Regression Test}

regress intdi audcma audcmc audcmi audcms

\begin{tabular}{|c|c|c|c|c|c|c|}
\hline Source | & SS & $d f$ & MS & Number of obs & $=$ & 220 \\
\hline Mode & 2313.38354 & 4 & 578.345885 & Prob $>F$ & $=$ & 0.0001 \\
\hline Residual & 20631.9832 & 215 & 95.9627124 & R-squared & $=$ & 0.1008 \\
\hline Total & 22945.3667 & 219 & 104.773364 & $\begin{array}{l}\text { Adj R-squared } \\
\text { Root MSE }\end{array}$ & $\begin{array}{l}= \\
=\end{array}$ & $\begin{array}{l}0.0841 \\
9.7961\end{array}$ \\
\hline
\end{tabular}

\begin{tabular}{r|rrrrrr} 
intdi | & Coef. & Std. Err. & \multicolumn{1}{c}{$t$} & $\mathrm{P}>|\mathrm{t}|$ & [95\% Conf. Interval] \\
audcma | & 2.632469 & .6646869 & 3.96 & 0.000 & 1.322331 & 3.942606 \\
audcmc | & 19.27367 & 5.174796 & 3.72 & 0.000 & 9.073844 & 29.4735 \\
audcmi | & -3.723874 & 5.363946 & -0.69 & 0.488 & -14.29653 & 6.848781 \\
audcms | & 1.162718 & .623799 & 1.86 & 0.064 & -.0668264 & 2.392263 \\
_cons | & 18.76341 & 5.941392 & 3.16 & 0.002 & 7.052573 & 30.47424
\end{tabular}

